\title{
A Rare Variation of the Retro-Aortic Left Renal Vein with Anastomotic Afluent from Inferior Mesenteric Vein
}

\author{
Una Variación Rara de la Vena Renal Izquierda Retro-Aórtica con \\ un Afluente Anastomótico de la Vena Mesentérica Inferior \\ F. M. Andrade; R. P. Rocha; H. M. Pereira; R. M. P. Fernandes \& M. A. Babinski
}

\begin{abstract}
ANDRADE, F. M.; ROCHA, R. P.; PEREIRA, H. M.; FERNANDES, R. M. P. \& BABINSKI, M. A. A rare variation of the retroaortic left renal vein with anastomotic afluent from inferior mesenteric vein. Int. J. Morphol., 23(1):5-8, 2005.

SUMMARY: We report an uncommon anatomical variations of the left renal vein was found on dissected specimen in an elderly male cadaver: a retroaortic left renal vein. No other vascular anomalies were noted in this specimen. The anomaly result may be related to a particular pattern of left inferior vena cava. The abnormality have to be known for it may be undetected or be misleading in imaging. This anatomical curiosity should be kept in mind by clinicians and academics that may manipulate this anatomical area.
\end{abstract}

KEY WORDS: Anatomy; Anomalies; Kidney; Retroaortic renal vein.

\section{INTRODUCCIÓN}

A knowledge of the variations of renal vascular anatomy has importance in exploration and treatment of renal trauma, renal transplantation, renovascular hypertension, renal artery embolization, angioplasty or vascular reconstruction for congenital and acquired lesions, surgery for abdominal aortic aneurysm and conservative or radical renal surgery (Sampaio \& Aragão,1990; Satyapal et al., 1999; Senecail et al., 2003).

Anatomical variations and congenital anomalies of the renal veins were well described by Gillot (1978) and Bergman et al. (1988). These anomalies in renal veins show less variation than to the renal arteries and the right renal vein may be doubled, even though the left renal vein is usually single (Testut \& Latarjet, 1947; Bergman et al.). Amongst the numerous variations of this vein, the retro-aortic course is much less well known (Bergman et al.; Satyapal et al.; Senecail et al.) and it seemed to us of value to present one case discovered during dissection of the retroperitoneal organs.

\section{CASE REPORT}

During dissection of the retroperitoneal region of an elderly male cadaver, a variant drainage pattern of the left renal vein was found. This anatomical variation observed was arising from retro-aortic vein (Fig. 1a for a schematic drawing, see Fig.1b). The trunk of the left renal vein was single over the initial $4 \mathrm{~cm}$ from the hilum and received, as normal, however dilated, the left suprarenal vein on its superior margin. In inferior margin received, as normal, the left testicular vein and two centimeters after (medial) this anastomosis, the left renal vein received an anastomotic afluent vein. This communicant vein to originate from inferior mesenteric vein (Figs. 1a and $1 b$ ). The variant left renal vein passed between the abdominal aorta and the lumbar column to drain into a single inferior cava in normal position. The opening of the retroaortic vein was with the left side of the inferior vena cava at the level of L2. From the arterial aspect the left kidney was supplied by a single artery which divided into two segmental branches penetrating the hilum. On the right, the renal vessels showed no particular anomalies in their origin, course, nor distribution.

\section{MATERIAL AND METHOD}

The work complies with the provisions of the declaration of Helsinki in 1995 (as revised in Edinburgh, 2000).

\section{DISCUSSION}

Anatomical variations and congenital anomalies of the left renal vein were well described by Gillot and Bergman et 
al. Sampaio \& Aragão reported the variants renal venous drainage and verified the Anatomical relationship between the renal venous arrangement and the kidney collecting system.

In his classification of the variations of the left renal vein, Gillot distinguished two situations depending on whether the left kidney was involved in the variation. In the case presented here, the left kidney was neither ectopic nor malformed and there were no associated arterial anomalies. In this situation, one type of variation may be encountered: the ectopic vein forming a single retro-aortic trunk, habitually running downwards.

It reproduced the retro-aortic trunk and peri-aortic venous collar of the embryonic period, of which it might be

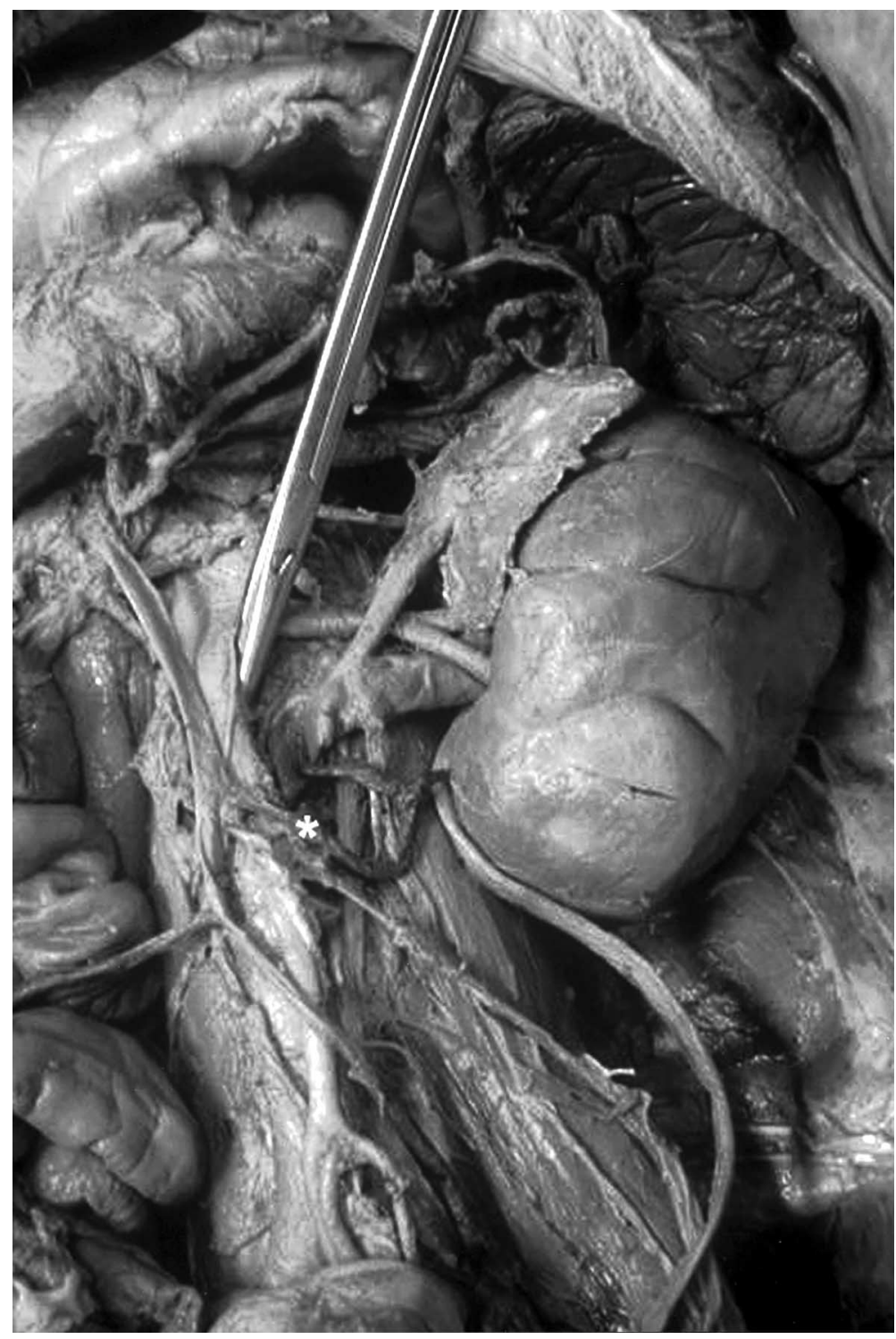

Fig. 1a. Photograph of the dissection of the retro-aortic left renal vein. Asterisk showing an anastomotic afluent from inferior mesenteric vein. considered as a form of abnormal persistence. Indeed from the eighth week, two anastomoses between the supracardinal and infracardinal veins are established respectively in front of and behind the embryonic aorta (Gillot; Senecail et al.). The usual evolution is marked by regression of the intersupracardinal retro-aortic anastomosis while the intersubcardinal pre-aortic anastomosis persists and gives rise to the left renal vein which is normally single and pre-aortic. The abnormal persistence of the supracardinal anastomosis, associated with regression of the inter-subcardinal anastomosis, leads to the development of a retro-aortic ectopic left renal vein while the persistence of the two pre- and retroaortic anastomoses leads to the development of a periaortic venous ring (Gillot; Senecail et al.).

Among a series of 1,008 kidneys studied by Satyapal et al., the type of partial distal bifurcation, resulting in a venous collar was seen in only $0.3 \%$. The retro-aortic left renal vein was reported here reveals another form of partial distal bifurcation represented by the retrocaval or retro-iliac arc which, according to Gillot who noted it 15 times, should be the primer of total bifurcation. Its relationship with the left inferior vena cava is real and this arrangement is the remnant of a lateral sympathetic vein. Determining its real statistical frequency is dificult due to the fact that it will be considered as much in series of retro-aortic veins as in those of bifid veins (Gillot; MartinezAlmagro et al. 1992; Satyapal et al.; Senecail et al.).

The normal anastomosis of the left suprarenal vein with the pre-aortic trunk seen in this case conforms to what seems to be the rule in the literature (Bergman et al.; Testut \& Latarjet), while in the second anastomosis of the afluent vein communicating the inferior mesenteric vein with the retro-aortic trunk presented here, still has not been seen described.

This type of anomaly of the left renal vein may represent real traps in the interpretation of abdominal imaging, particularly in CT scanning (Cocheteux et al., 2001), where he is not always recognized (Martinez-Almagro et al.), or in magnetic resonance imaging (Carriero et al., 1994). They may be the source of technical dificulties in diagnostic or therapeutic angiography (Gillot) and may modify the values obtained by catheter sampling for suprarenal hormonal levels 


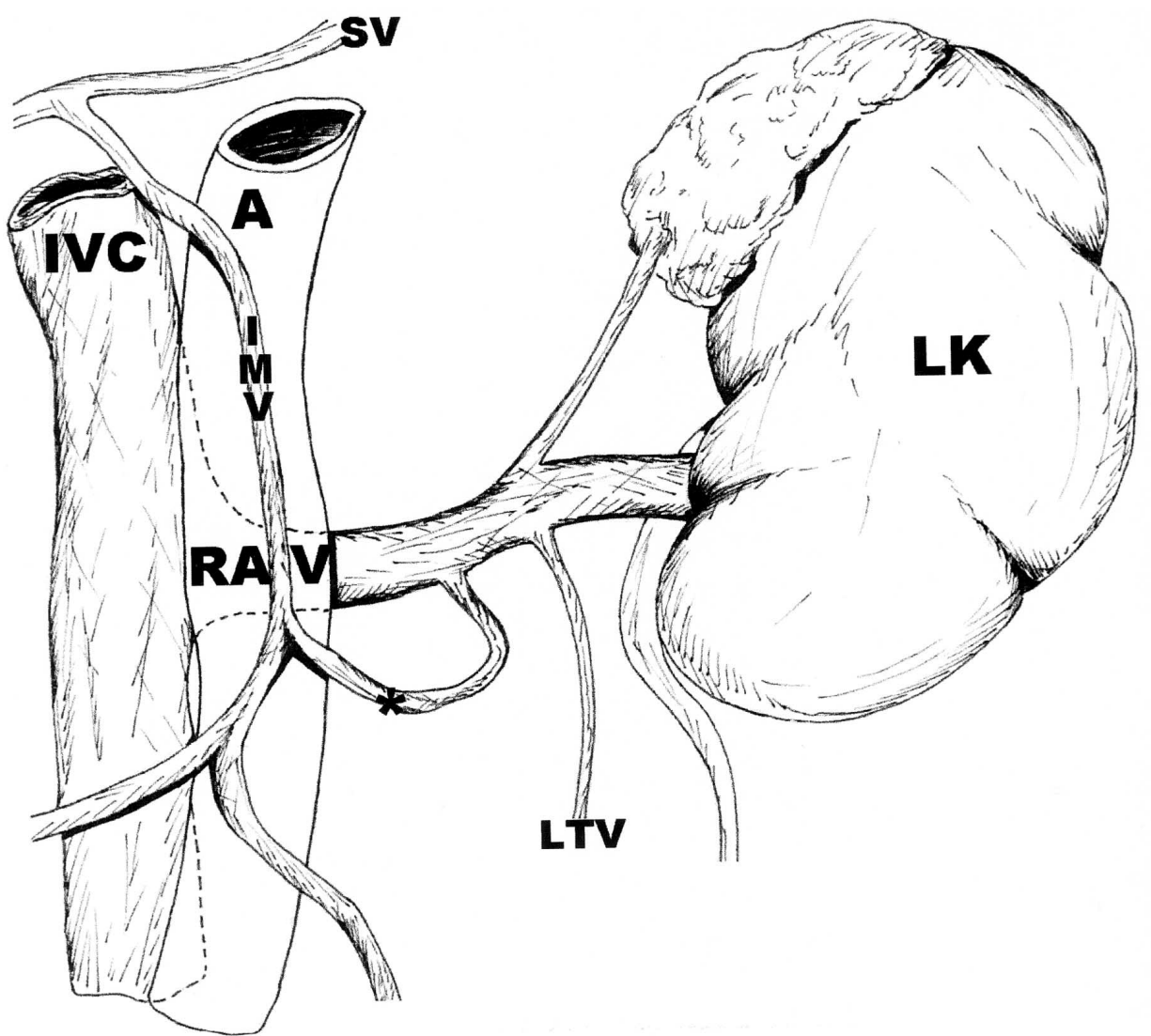

Fig. 1b. Drawing of the anomaly. LK= left kidney; RAV= retro-aortic vein; IVC= inferior vena cava; $\mathrm{A}=$ aorta; $\mathrm{IMV}=$ inferior mesenteric vein; $\mathrm{SV}=$ splenic vein; $\mathrm{LTV}=$ left testicular vein and asterisk $(*)=$ anastomotic communicant vein.

(Satyapal et al.). According Sencecail et al. and MartinezAlmagro et al., the presence of a retro-aortic left renal vein gives rise to a risk of venous compression analogous to that of the pre-aortic venous ring but it is theoretically less important.

The effect on the venous drainage of the ipsilateral gonad is a function of the anastomosis of the gonadal vein into the retro-aortic trunk. The left renal vein in this form of case present one of the anatomical causes of failure of prophylaxis for pulmonary embolus by placement of a caval filter immediately below the anastomosis of the renal veins (Senecail et al.).

From a more general point of view, any retroperitoneal surgery requiring mobilization or hemostatic control of the left renal vein and its afluents requires a systematic search for any possible anomalies of the retro-peritoneal veins (Sampaio \& Aragão; Satyapal et al.; Surucu et al., 2001; Senecail et al.). Particularly in renal transplantation, the complexity of the anomalies of the left renal vein may modify the technical possibilities of the surgical procedure (Sampaio \& Aragão; Satyapal et al.).

ANDRADE, F. M.; ROCHA, R. P.; PEREIRA, H. M.; FERNANDES, R. M. P. \& BABINSKI, M. A. Una variación rara de la vena renal izquierda retro-aórtica con un afluente anastomótico de la vena mesentérica inferior. Int. J. Morphol., 23(1):5-8, 2005.

RESUMEN: Relatamos una variación anatómica infrecuente de la vena renal izquierda, denominada vena renal retroaórtica, encontrada en un cadáver masculino disecado. No se observaron otras variaciones vasculares. Lavariación anatómica encontrada se puede relacionar con un patrón particular de la vena cava inferior izquierda. La variación debe ser conocida ya que puede pasar inadvertida o ser confundida en proyecciones de imágenes de la región. Los clínicos y académicos que actúen en la región, deben considerar esta eventual variación anatómica.

PALABRAS CLAVE: Anatomía; Anomalías; Riñón; Vena renal retroaórtica. 


\section{REFERENCES}

Bergman, R. A.; Thompson, S. A.; Afifi, A. K. \& Saadeh, F. A. Compendium of Human Anatomic Variation: Catalog, Atlas and World Literature. Baltimore. Urban \& Schwarzenberg, 1988.

Carriero, A.; Magarelli, N.; Tamburri, L.; Tonni, A.G.; Lezzi, A.; Bonomo, L. Magnetic resonance angiography of the left renal vein. Surg. Radiol. Anat., 16:205-9, 1994.

Cocheteux, B.; Mounier-Vehier, C.; Gaxotte, V.; McFadden, E. P.; Francke, J.P.; Beregi, J. Rare variations in renal anatomy and blood supply: CT appearances and embryologic background. A pictorial essay. Eur. Radiol., 11:779-86, 2001.

Gillot, C. La veine rènale gauche: ètude anatomique, aspects angiographiques, abord chirurgical. Anat. Clin., 1:135-55, 1978.

Martinez-Almagro, A.; Almenar-Garcia, V.; Martinez-Sanjuan, V.; Hernandez, Gil-de-Tejada, T. \& Lorente-Montalvo, P. Retroaortic left renal vein: a report of six cases. Surg. Radiol. Anat., 14:361-6,1992.

Sampaio, F. J. \& Aragão, A. H.M. Anatomical relationship between the renal venous arrangement and the kidney collecting system. J. Urol., 144:1089-93, 1990.

Satyapal, K. S.; Kalideen, J. M.; Haffejee, A. A.; Singh, B. \& Robbs, J. V. Left renal vein variations. Surg. Radiol. Anat., 21: 77-81, 1999.

Senecail, B.; Bobeuf, J.; Forlodou, P.; Nonent, M.Two rare anomalies of the left renal vein. Surg. Radiol. Anat., 25: 465-7, 2003.
Surucu, H. S.; Erbil, K. M.; Tastan, C. \& Yener, N. Anomalous veins of the retroperitoneum: clinical considerations. Surg. Radiol. Anat. 23:443-5, 2001.

Testut, L. \& Latarjet, A. Tratado de Anatomía Humana. 8 ed. Barcelona, Salvat Editores, 1947.

Correspondence to:

Prof. Márcio Antônio Babinski

Departamento de Anatomia

Instituto de Biologia

Av. 28 de Setembro, 87 ( $f d s)$

CEP 20551-030

Rio de Janeiro- $R \mathcal{O}$

BRASIL

Fax: ++ (55) (21) 2587-6121

E-mail:babinski@vm.uff.br 6abinski3@6ol.com.6r

Received : 22-09-2004

Accepted: 10-12-2004 